\title{
FLOOD MODELING OF RIVER GODAVARI USING HEC-RAS
}

\author{
Sunil Kute ${ }^{1}$, Sayali Kakad ${ }^{2}$, Vrushali Bhoye ${ }^{3}$, Akshada Walunj ${ }^{4}$ \\ ${ }^{\text {I}}$ Professor, Department of Civil Engineering, K.K.Wagh Institute of Engineering Education \& Research (University of \\ Pune), Maharashtra, India \\ ${ }^{2}$ Student, Department of Civil Engineering, K.K.Wagh Institute of Engineering Education \& Research(University of \\ Pune), Maharashtra, India. \\ ${ }^{3}$ Student, Department of Civil Engineering, K.K.Wagh Institute of Engineering Education \& Research(University of \\ Pune), Maharashtra, India \\ ${ }^{4}$ Student, Department of Civil Engineering, K.K.Wagh Institute of Engineering Education \& Research(University of \\ Pune), Maharashtra, India
}

\begin{abstract}
Many cities and towns are developed on downstream side of dams. Some of them are established on the banks of river. During the monsoon period, when the dam is full at its Maximum Reservoir Level (MRL) and still the surplus floods are approaching into dam submergence, the maximum discharge is released from the dam to avoid the overtopping. This results into floods on downstream and may cause the disaster in cities or towns settled on banks of rivers. To facilitate the appropriate measures for effective flood mitigation in advance, there is a need to model the flood plain. With the advent of modern technology, the use of sophisticated softwares in flood modeling helps in getting an idea of extent of flood at its submergence. This paper presents a case study of Godavari river flood modeling using HEC-RAS software. The flood released for Gangapur dam, which is constructed on upstream of Nashik city at $14 \mathrm{~km}$ distance is considered for the modeling. The flood discharge is based on the worst discharge of 1969 flood. The river, 14 bridges across the river and the flood plain are modeled. The model facilitates to locate the flood plain and its extent for effective flood mitigation measures.
\end{abstract}

Keywords: Flood modeling, Godavari River HEC-RAS Return Period.

\section{INTRODUCTION}

The flood modeling is one of the engineering tools which provide accurate information of the flood profile. The rainfall, runoff, catchment characteristics, and return period are the parameters which govern the flood. These parameters are used as input variables along with cross section and L section of river. Ibrahim, G. and Ibrahim U; Brych, K, Dittrt and Elis, V; Morankar, D.V. and Awate V; have attempted the hydraulic modeling using soft computing tools \& [1, 2, 3 ]. Also Merwade, V, Cook A. and Coonrod, J; Yi Xinog; Eric Tate, M.S.E. and Maidment D; Manadhar, B, Balla, M.K, Awal, R, Pradhan, B; have used different parameters as variables and found that hydraulic modeling is an effective tool for the mitigation measures.[4, 5, 6, 7 ]

River Godavari flows through Nashik city. The river has almost $10 \mathrm{~km}$ reach passing trough city. The population of Nashik city is about 18 lakh and the city has historical significance. The Sinhanstha Kumbh-mela is held after every 12 years in Nashik during which the floating population of about 20 lakh devotees visit Nashik for holy bath. The flood, either due to heavy rainfall or dam break may cause a disaster and the mitigation measures are possible in advance only if the engineering tools such as flood modeling are adopted. HEC-RAS (Hydrologic Engineering Centre- River Analysis System) is numerical analysis software which provides the details of flood profiles. The software is easily available and has precise calibration accuracy.

\section{PROBLEM FORMULATION AND STUDY} AREA

The flood modeling of river Godavari was done at the Ramkund site where holy bath by about 40 lakh persons takes place. This section of river is at a distance of about 14 $\mathrm{km}$ from the Gangapur dam as shown in Figure 1.

Following input parameters were used as data for the modeling -

1. Catchment area $=357.40 \mathrm{sq} . \mathrm{km}$.

2. Max. flood intensity $=20385.93 \mathrm{~mm} / \mathrm{sec}$

3. Cross section of Ramkund at Godavari.

4. Alignment details of river and dam.

5. Contours details of river cross section at Ramkund.

\section{FLOOD MODELING AND DISCUSSIONS}

The flood modeling using HEC-RAS was performed in following steps. The analysis of each step is presented in form of output in print screen mode.

\subsection{Storage Area Data}

An area which is like lake in which water can flow into and out of and is connected to the river reach by lateral structure connections is known as storage area. In this study, the storage area i.e. Gangapur dam is at the upstream side of Godavari river reach. The connection consists of gated spillway and a weir. The gross storage area of dam is 
$7600 \mathrm{Mcft}$. The maximum height of Gangapur dam is $36.58 \mathrm{~m}$ above the river bed. For computation in the software, volume is considered as zero for first elevation to get elevation and volume curve relationship. In this step, the area of reservoir is traced and the data is entered in the storage area editor as shown in figure 2 .

\subsection{Inline Structure Data}

Gangapur dam is having total length $3811 \mathrm{~m}$ out of which $101.82 \mathrm{~m}$ is length of gated spillway in left side saddle. Nine radial gates having maximum opening height $6.1 \mathrm{~m}$ are provided on overflow section with 81,000 Cusecs discharge capacity. The necessary data for calculating the weir flow between two storage areas is weir width, weir coefficient and crest shape and it is used for schematic diagram, flow calculations and submergence criteria. The gated spillway is added to the structure using the gate data editor. Also, physical description and required coefficient of gate is entered in HEC-RAS as shown in figure 3 and 4.

\subsection{Geometric Data}

In present study, the geometric data i.e. cross section data at the Ramkund section is entered which includes the cross section of river at Ramkund and the adjoining contours at that section. This data will give the horizontal spread of the water at the particular discharge in the adjoining area. At Ramkund section, the lowest level of the river is $557.1 \mathrm{~m}$ which is at the center of cross section. The value of the cross section describes the section data referring to other section within the reach. The data to be entered is from upstream to downstream direction of the river in geometric data editor of HEC-RAS as shown in figure 5.

\subsection{Entering Flow Data and the Boundary}

\section{Conditions}

The type of flow data entered depends upon the type of analysis to be performed in the project. In present paper, the steady flow analysis is performed. The discharge $18,000 \mathrm{cu} . \mathrm{m} / \mathrm{sec}$ is considered for the worst flood condition. It includes the flow data, number of profiles computed and river system boundary conditions. Boundary conditions are required to perform the calculations. In this study, the normal depth is used as a boundary condition and steady flow data and gate opening schedule is entered. As the worst flood is considered in the present modeling, all the gates are opened to their full extent. The flow data entered in HECRAS is shown in figure 6 .

\subsection{Results}

After giving all the input parameters to the software for the computation, the output in terms of the table and the graphs is obtained which includes:

In the cross section output the value of ground elevation, velocity head, water surface elevation, total velocity, max channel depth, losses, average velocity, wetted perimeter etc. This output is presented in figure 7.
For the given discharge, the submergence at the given section is also, shown which shows the level of flood and is shown in figure 8.

The rating curve is also derived i.e. graph between water surface elevation and discharge at the given flood at a given cross section. This gives the idea about the water level at different discharge values shown in figure 9.

\section{CONCLUSIONS}

1) The HEC-RAS provides the flood profile for the worst flood intensity. This profile will facilitate to adopt appropriate flood disaster mitigation measures.

2) The flood profiles for different flood intensities with different return periods can be plotted at any given cross section of river. Also, such flood profile can be plotted for entire length of river reach.

3) Flood modeling using HEC-RAS is effective tool for hydraulic study, handling of disaster management measures.

\section{ACKNOWLEDGEMENTS}

The execution of this paper has been possible due to help of Er. Tushar Chaudhari. Also, the help and guidance of Er. Prakash Nikumbh is thankfully acknowledged. The authors are thankful to Er. Harshita Ambre. Due to her constant help and association in field work and soft computing, this work has taken a shape.

\section{REFERENCES}

[1]. Ibrahim Gurer and Ibrahim Ucar, "The importance of flood zoning- A case study from Macka, Trabzon, Northeastern Turkey", A research supported by Scientific Research Council of Gazi University, 2010, pp-1-8.

[2]. Brych, K; Dittrt; Elias, V; "Development of flood boundry maps of urban areas using HEC-RAS", Proceeding of Fourth International FRIEND Conference, Cape Town, South Africa, 2002, pp-237-242.

[3]. Morankar, D.V. Awate, V.; "Hydraulic model computations using HEC-RAS- A case study", Journal of Indian Water Works Association, Jan-March, 2012, pp.7280.

[4]. Merwade, V, Cook A. and Coonrod, J.; "GIS Techniques for creating river terrain models for hydrodynamic modeling and flood inundation mapping.", Environmental Modeling and Software 23(2008).

[5]. Yi Xinog;“'A dam Break analysis using HEC-RAS.”, Journal of Water Resource and Protection, 2011.

[6]. Eric Tate, M.S.E. and Maidment D.; "Floodplain mapping using HEC-RAS and arc view GIS.", Journal of Hydrologic Engineering, March-April 2002

[7]. Manadhar, B, Balla, M.K, Awal, R and Pradhan, B.; "Floodplain analysis and risk assessment of lothar khola (stream).", $11^{\text {th }}$ ESRI India User Conference 2010. 


\section{BIOGRAPHIES}

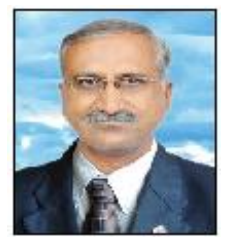

Dr.Sunil Kute: He is currently Professor of Civil Engineering Also; he is chairman, Board of Studies (Civil Engineering) and member of academic council and senate of University of Pune. He has experience of 23 years in teaching, administration and research. He is $\mathrm{Ph}$. D guide of University of Pune and North Maharashtra University. His 45 research papers are published in journals and conferences. His research areas are structural engineering and water resources engineering currently 6 students are pursuing Ph.D. under his guidance.

Sayali Kakad: She is pursuing her engineering studies at Dept of civil engineering, K.K. Wagh Institute Of Engineering Education \& Research, Nashik, Maharashtra. Her research area includes water resources \& construction management.

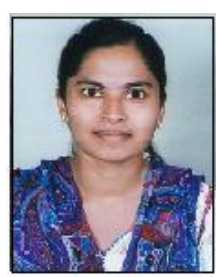

Akshada Walunj: She is pursuing her engineering studies at Dept of civil engineering, K.K. Wagh Institute of Engineering Education \& Research, Nashik, Maharashtra. Her research area includes water resources \& construction management.

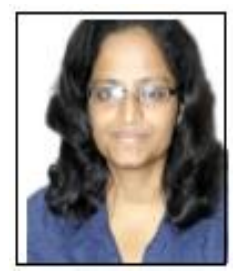

Akshada Walunj: She is pursuing her engineering studies at Dept of civil engineering, K.K. Wagh Institute of Engineering Education \& Research, Nashik, Maharashtra. Her research area includes water resources \& construction management.

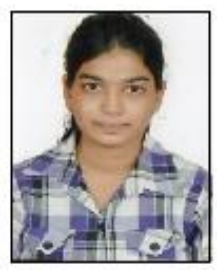

Vrushali Bhoye: She is pursuing her engineering studies at Dept of civil engineering, K.K. Wagh Institute of Engineering Education \& Research, Nashik, Maharashtra. Her research area includes water resources \& construction management.

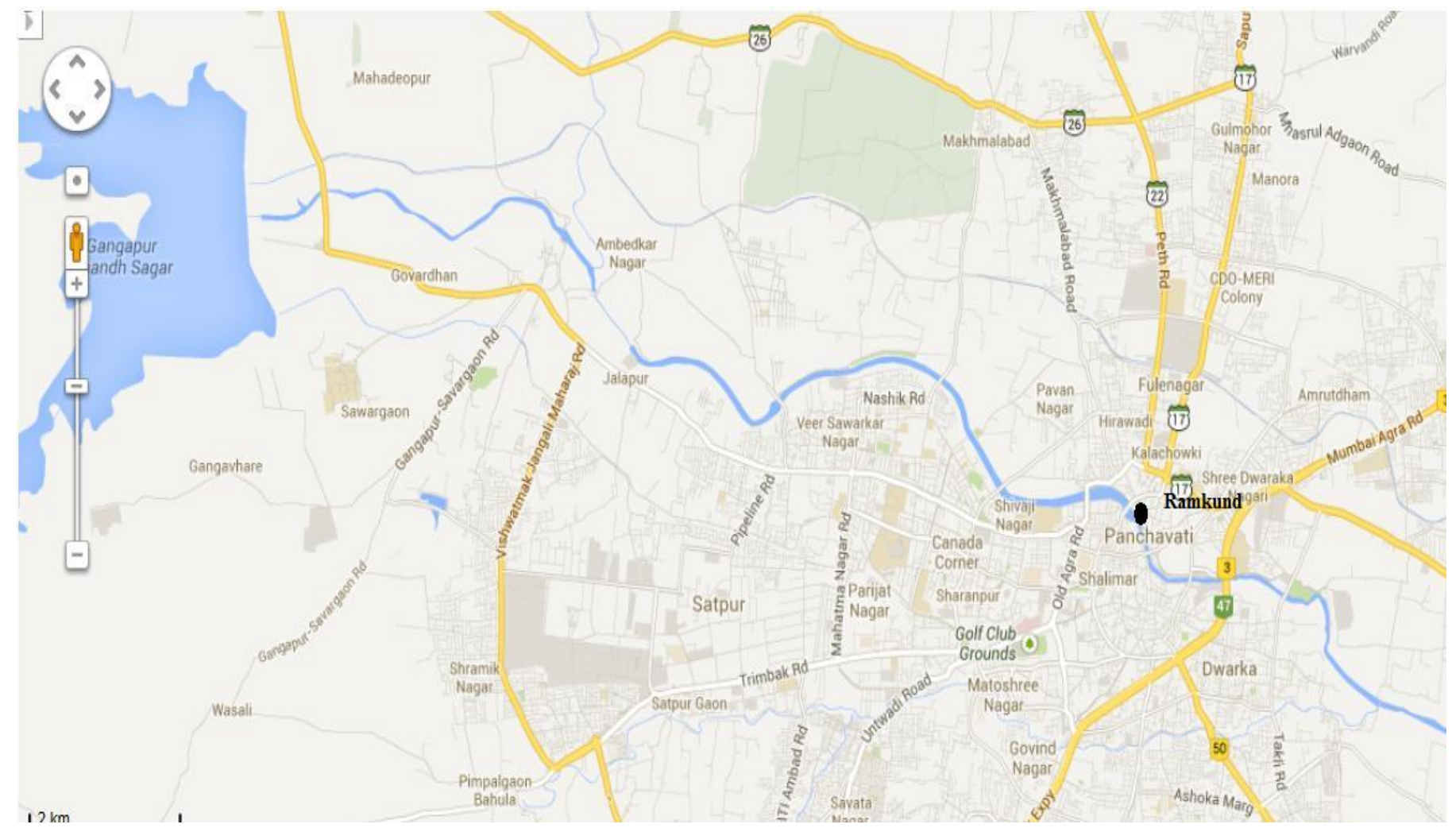

Fig -1: Map of study area showing Ramkund 


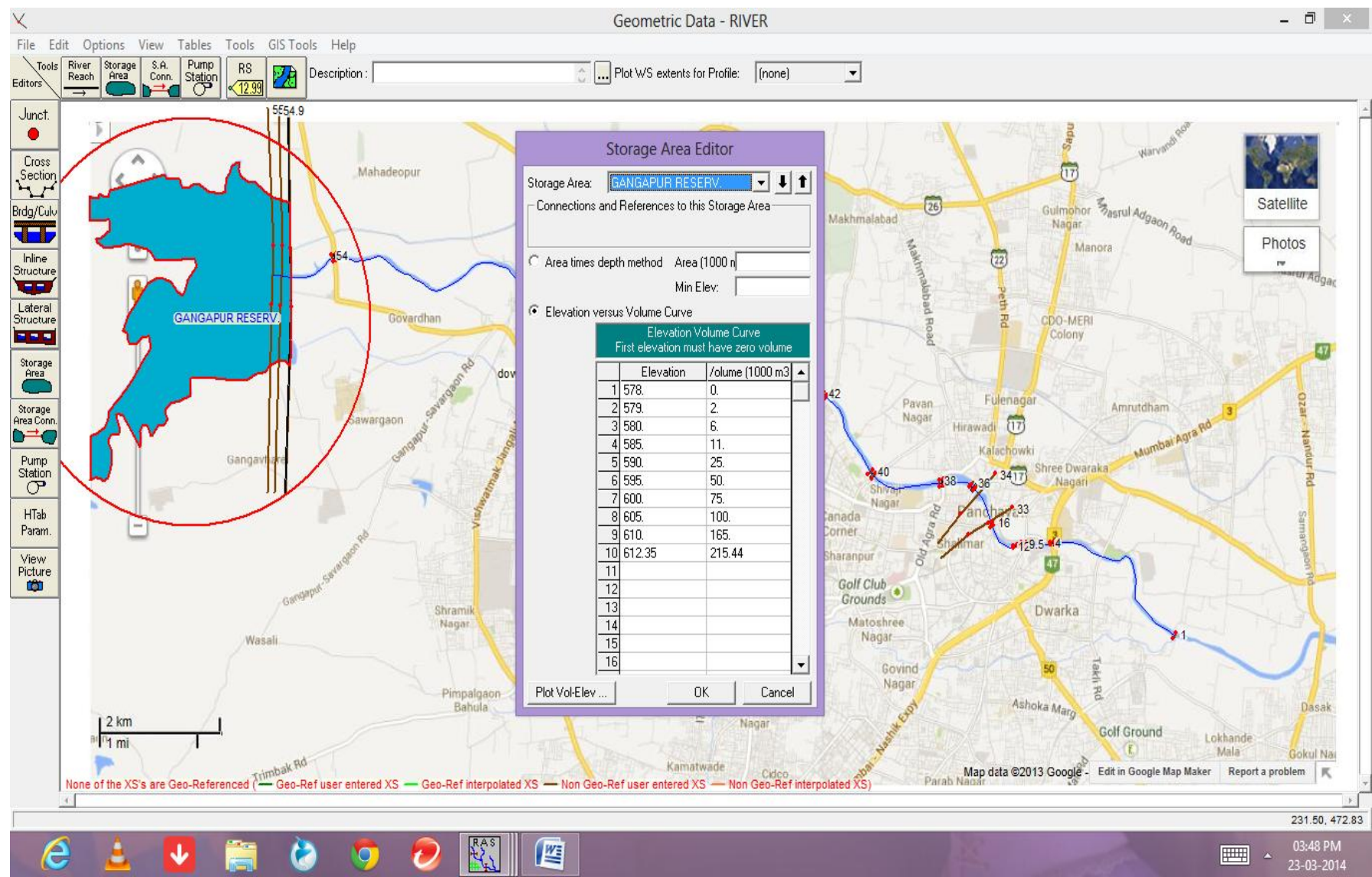

Fig -2: Storage area editor

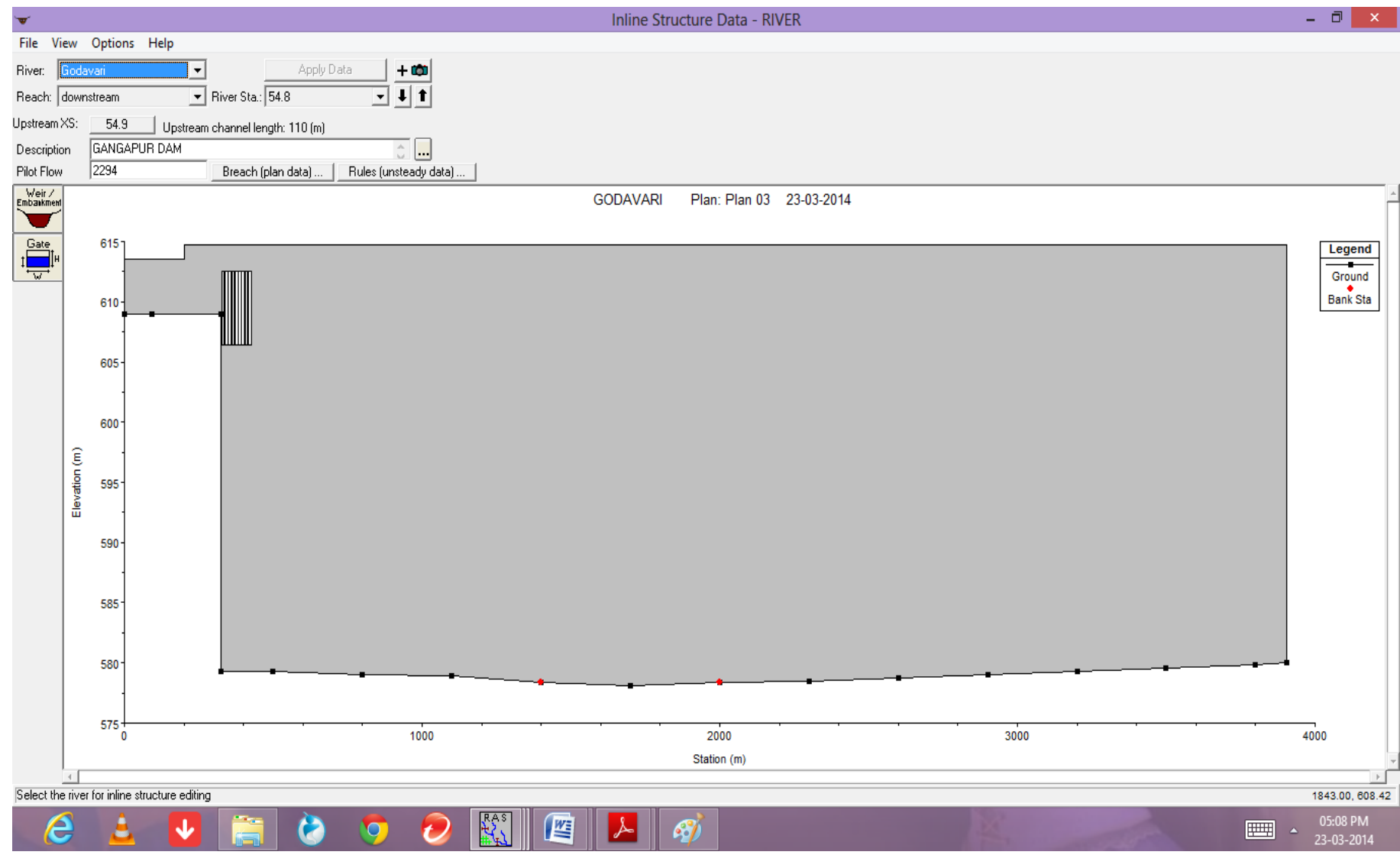

Fig -3: Inline structure data 


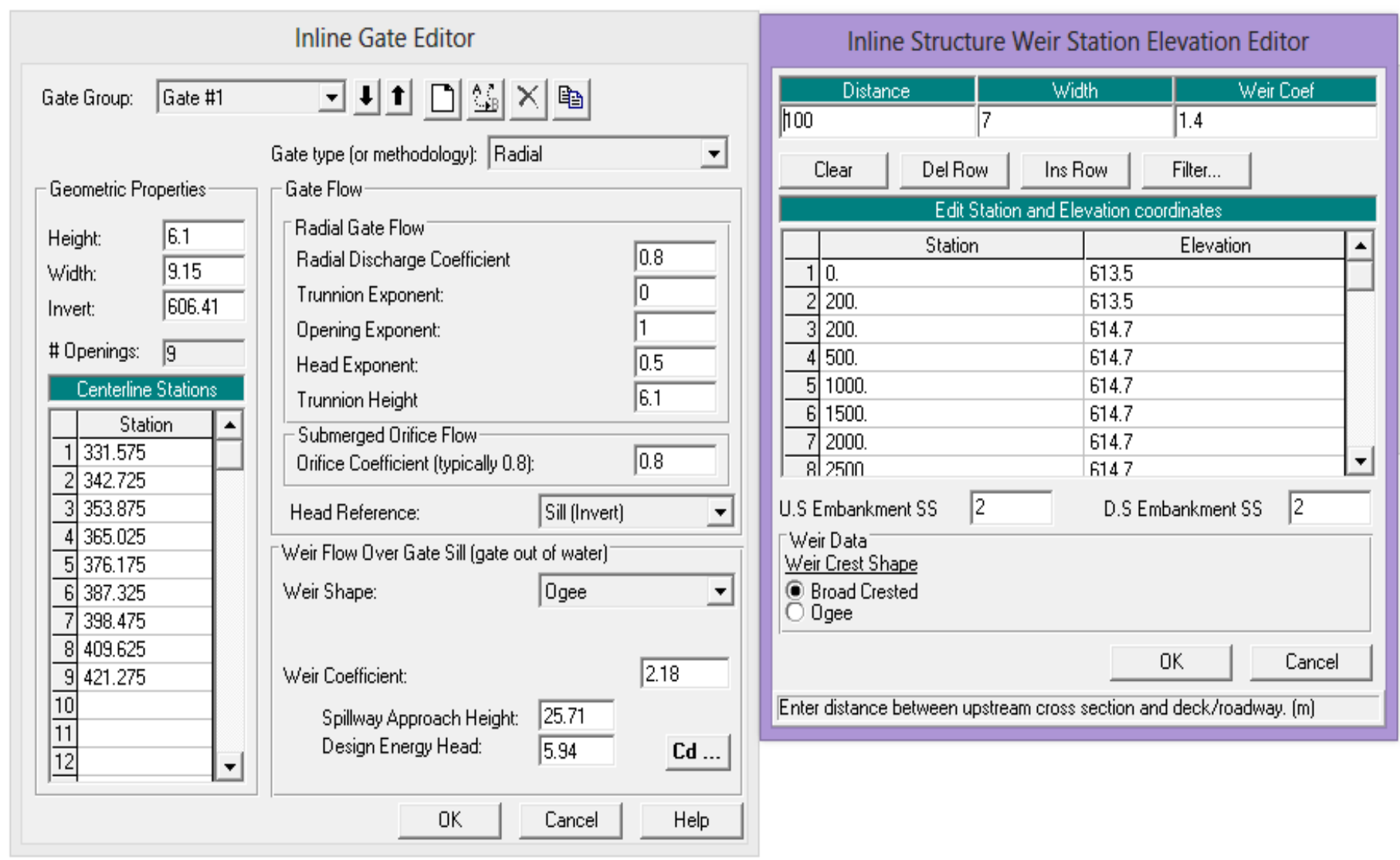

Fig -4: Gate and weir data

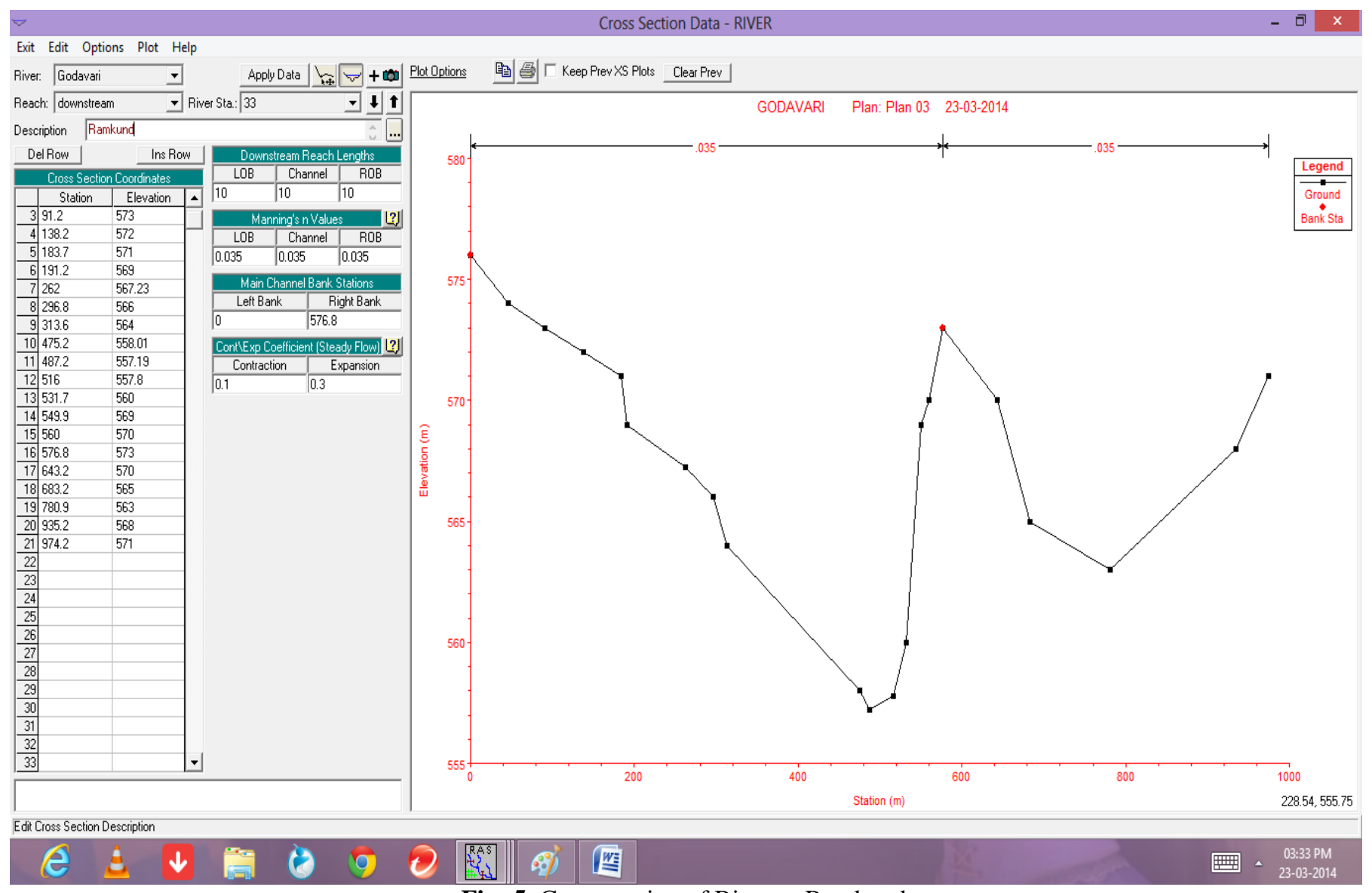

Fig -5: Cross section of River at Ramkund 


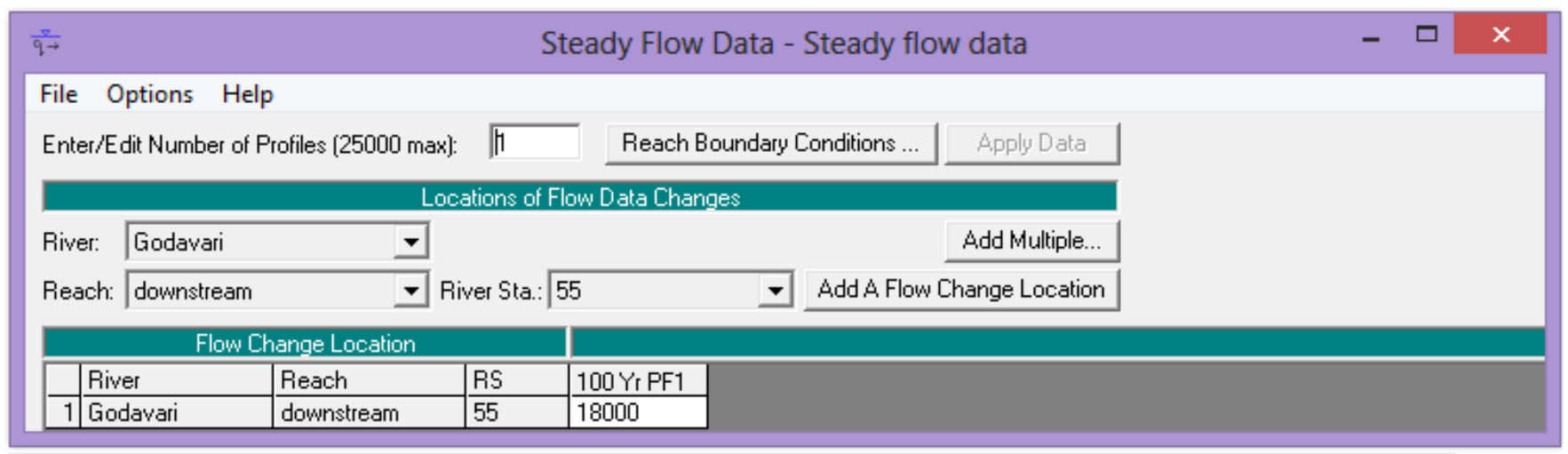

Spillway Gate Openings

$\begin{array}{llll}\text { Gate: } & \text { Godavari downstream } 54.8 & \text { \# Gate groups: } & 1\end{array}$

\begin{tabular}{|c|c|c|c|c|c|c|}
\hline Gate Group & \# Openings & Gate $\mathrm{Ht}$ & $100 Y_{r} P F$ & & & \\
\hline & & [m] & \# Open & Open Ht & & \\
\hline \multirow[t]{2}{*}{ Gate \#1 } & $\overline{9}$ & 6.1 & 9 & 6.1 & & \\
\hline & & & & & OK & Cancel \\
\hline
\end{tabular}

Fig -6: Steady flow data and spillway gate opening

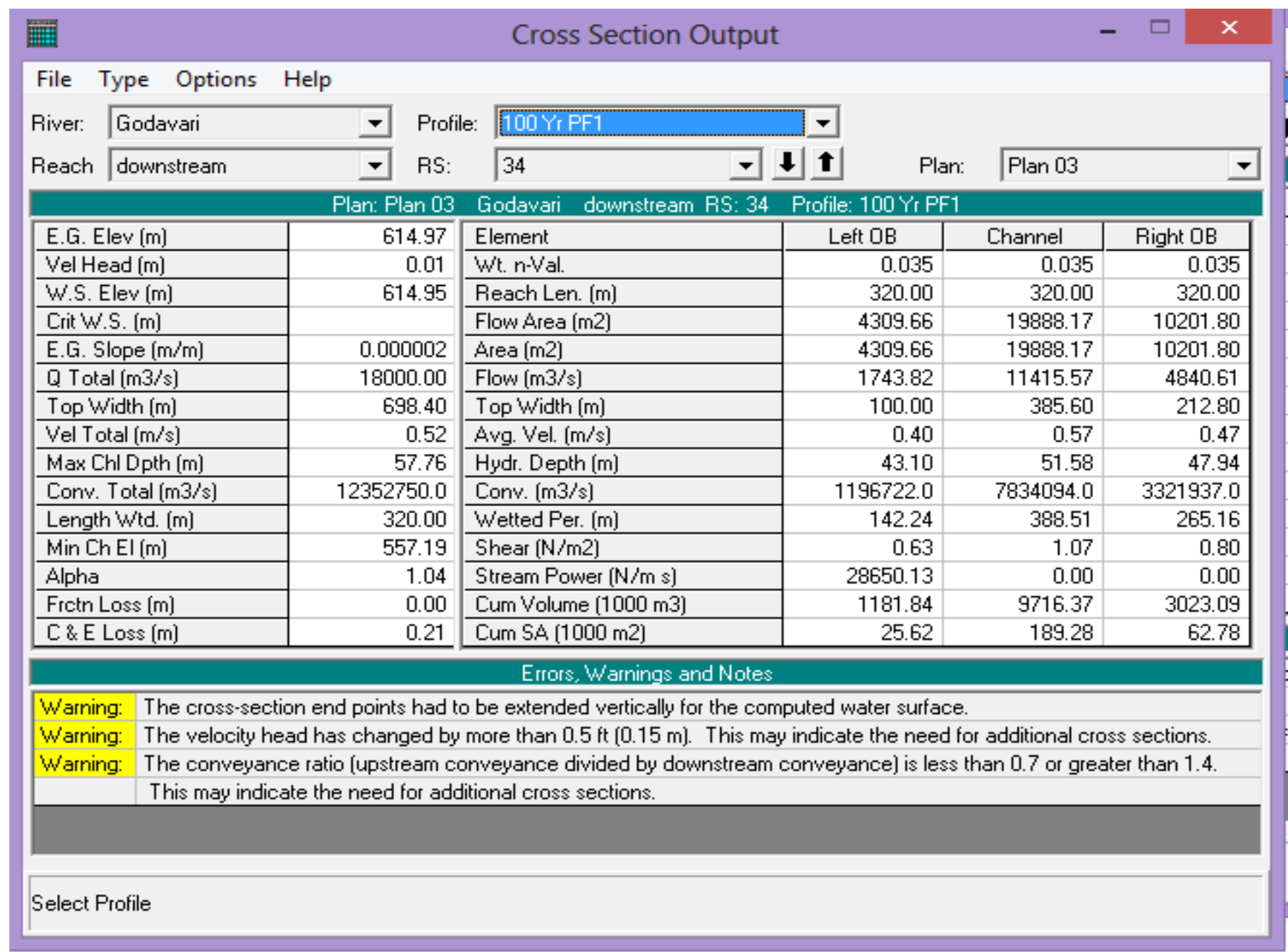

Fig -7: Cross section output 


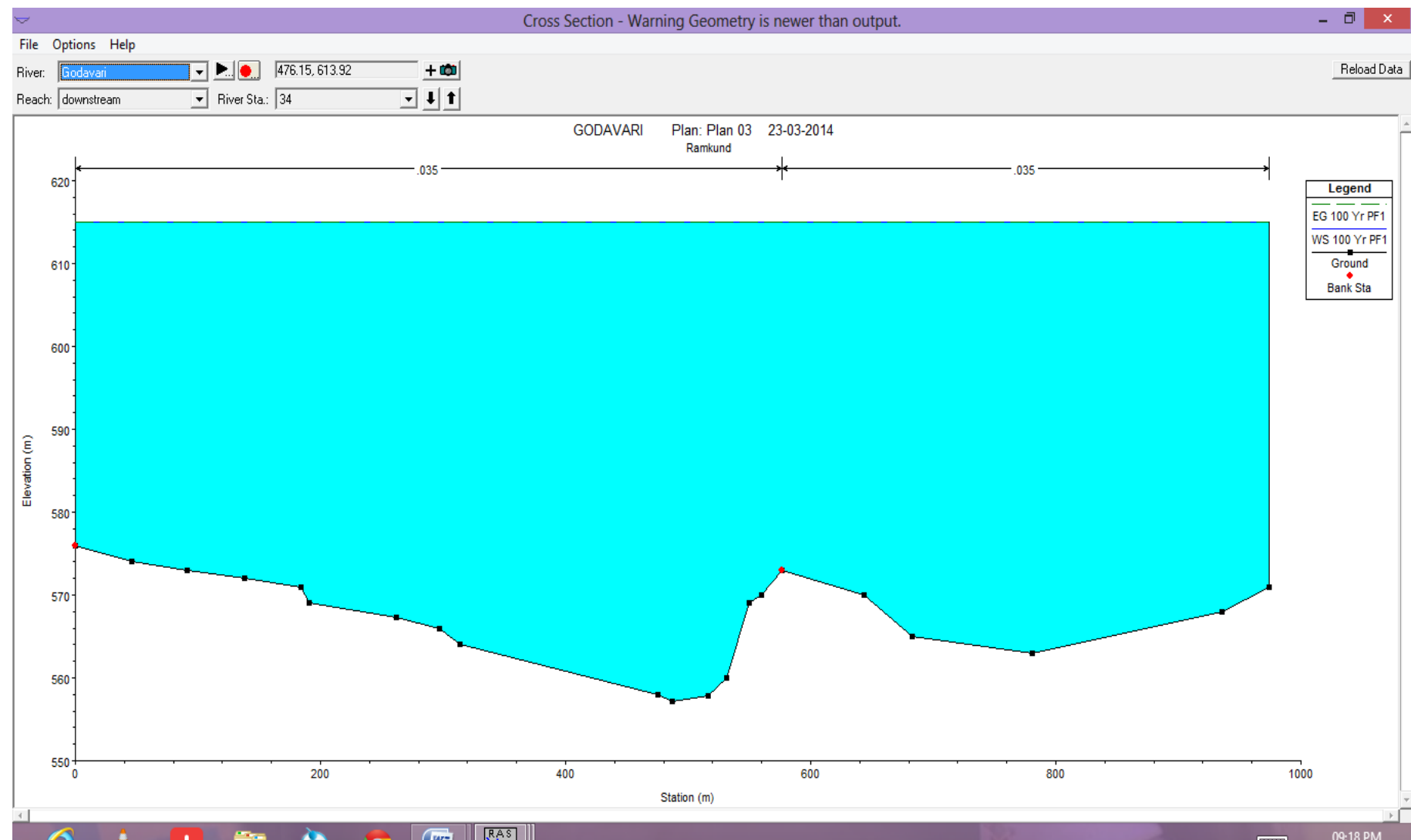

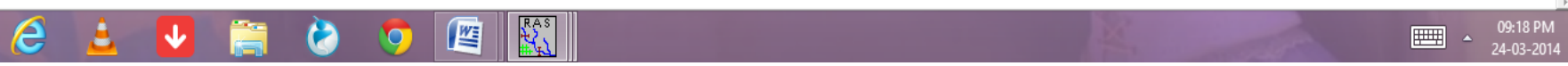

Fig -8: Level of flood for 100 years return period discharge

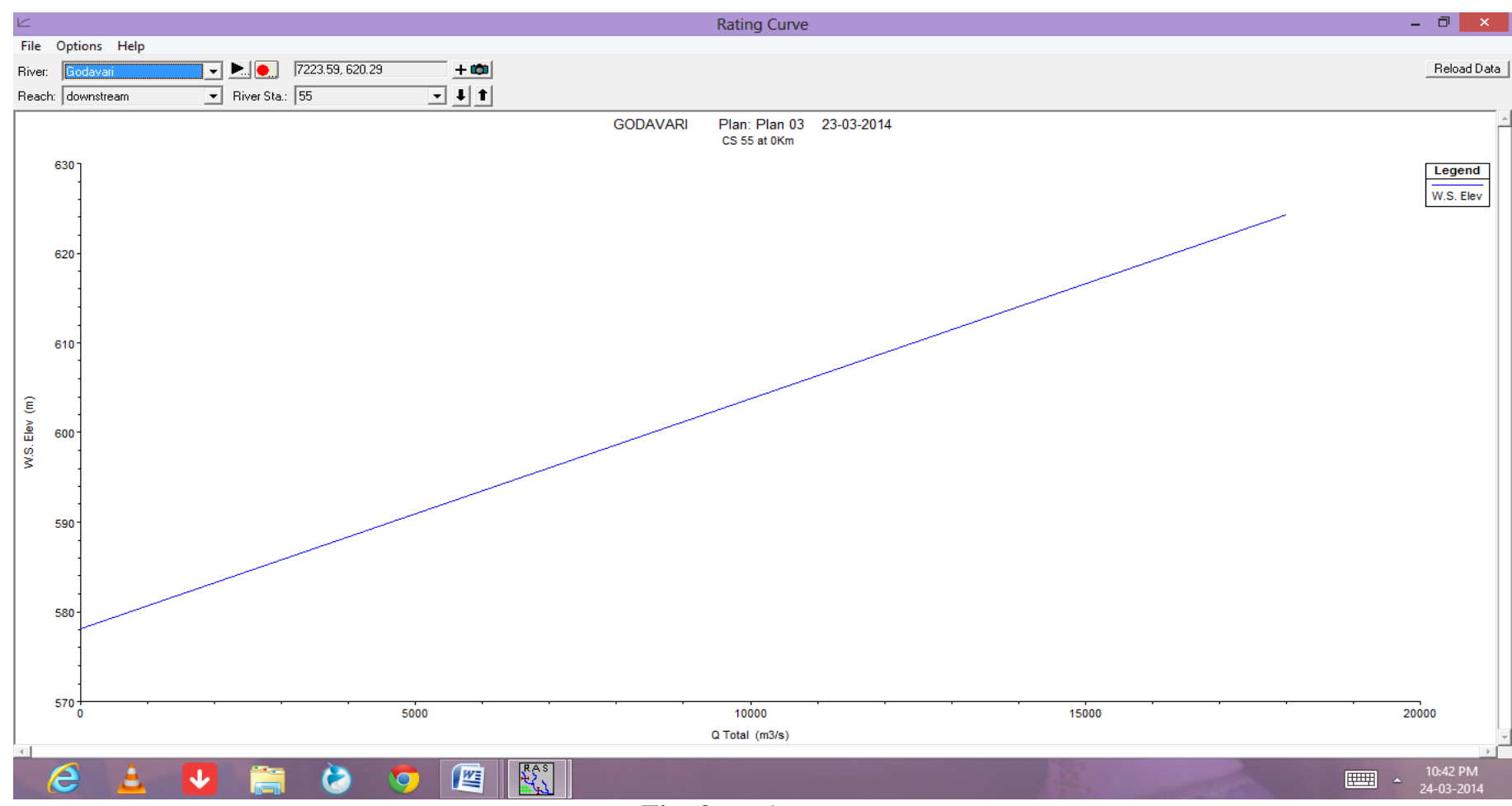

Fig -9: Rating curve 